\title{
Sprawozdanie z ogólnopolskiej Konferencji Naukowej Dyskurs (para)medyczny. Gatunki, funkcje, przeobrażenia, Wroclaw, 7-8.12.2017
}

W dniach 7-8 grudnia 2017 roku w Instytucie Filologii Polskiej Uniwersytetu Wrocławskiego odbyła się ogólnopolska konferencja naukowa zatytułowana Dyskurs (para)medyczny. Gatunki, funkcje, przeobrażenia, którą zorganizowali pracownicy Zakładu Edytorstwa Uniwersytetu Wrocławskiego. Przewodniczącym komitetu organizacyjnego był dr hab. Waldemar Żarski, prof. UWr. Intencją organizatorów było zainicjowanie dyskusji naukowej przedstawicieli różnych dyscyplin naukowych, których zainteresowania badawcze skupiają się na zagadnieniu dyskursu (para)medycznego. W sympozjum wzięło udział ponad 50 naukowców z polskich ośrodków naukowych oraz jeden z zagranicy.

Reprezentowane były następujące polskie szkoły wyższe: Instytut Slawistyki Polskiej Akademii Nauk (dr hab. prof. IS PAN Lucyna Jankowiak), Państwowa Wyższa Szkoła Zawodowa w Tarnowie (prof. dr hab. Joanna Okoniowa), Uniwersytet Medyczny im. Piastów Śląskich we Wrocławiu (prof. dr hab. Bożena Płonka-Syroka, dr Edyta Rudolf), Uniwersytet im. Adama Mickiewicza w Poznaniu (dr hab. prof. UAM Barbara Walkiewicz, dr hab. Magdalena Graf, mgr Beata Koper, mgr Andrzej Jędrzejczak, dr Joanna Smól, dr Magdalena Zabielska, dr Karolina Waliszewska, Uniwersytet Wrocławski (dr hab. prof. UWr Waldemar Żarski, dr hab. prof. UWr Edyta Zierkiewicz, dr hab. Aneta Firlej-Buzon, dr Jan Kamieniecki, mgr Adam Dombrowski, dr Anna Burzyńska-Kamieniecka, mgr Natalia Dobrzeniecka, dr Marcelina Kałasznik, mgr Anna Śliwicka, mgr Tomasz Piasecki, dr Tatiana Vologdina, mgr Kamil Wabnic, mgr Maria Rudnicka), Uniwersytet Mikołaja Kopernika w Toruniu (dr Agnieszka Sowińska, mgr Paula Wydziałkowska, mgr Anna Dwojnych), Uniwersytet Warszawski (dr Marta Chojnacka-Kuraś, mgr Anna Kujawska-Kot, mgr Aleksandra Grąbkowska, mgr Aleksandra Szugajew), Uniwersytet Śląski (dr Monika Ładoń, dr Renata Kozieł), Uniwersytet Zielonogórski (dr hab. Piotr Kładoczny), Uniwersytet Wileński (dr Aistis Žalnora), Akademia Muzyczna im. Ignacego Jana Paderewskiego w Poznaniu (dr Małgorzata Okupnik), Wydział Humanistyczny Uniwersytetu Przyrodniczo-Humanistycznego W Siedlcach (dr hab. prof. UPH Andrzej Borkowski), Uniwersytet w Białymstoku (lic./ lic. Edyta Saniewska, Natalia Saniewska, mgr Patrycja Saniewska, dr Diana Saniewska), Uniwersytet Łódzki (mgr Magdalena Nowakowska, mgr Ada Florentyna Pawlak), Uniwersytet Jana Kochanowskiego w Kielcach (dr hab. Katarzyna Szmigiero), Uniwersytet w Wilnie (dr Aistis Žalnora).

1 Konferencja odbyła się w ramach projektu (zadania badawczego) finansowanego w ramach działalności statutowej - działanie służące rozwojowi młodych naukowców prowadzonych w IFP UWr pt .Konferencja naukowa: Dyskurs (para)medyczny - gatunki, funkcje, przeobrażenia / The (para)medical discourse - genres, functions, transformations - organizacja (nr projektu: 0420/2580/17). 
Konferencję otworzył i przywitał wszystkich przybyłych gości dyrektor Instytutu Filologii Polskiej Uniwersytetu Wrocławskiego - dr hab. Paweł Kaczyński, prof. UWr, który przypomniał sylwetkę Władysława Nehringa, który był wybitnym znawcą historii języka polskiego.

Po inauguracji miały miejsce obrady plenarne. Część referatową rozpoczęła prof. dr hab. Joanna Okoniowa, która wygłosiła referat pt. Szlachetne zdrowie - dyskurs medyczny w staropolszczyźnie w którym omówiła najważniejsze sposoby kształtowania sie dyskursu na temat zdrowia w czasach staropolskich. Celem badawczym była analiza realizacji dyskursu medycznego i paramedycznego z uwzględnieniem tekstów XVI i XVII wiecznych poświęconych medycynie, a w szczególności dzieł Wojciecha Oczki i Erazma Sykstusa. Jako druga głos zabrała prof. dr hab. Bożena Płonka-Syroka, która przedstawiła referat pt. Samoleczenie na podstawie autodiagnozy i problemy z nim związane, prezentujące ważne spojrzenie historyka medycyny na temat poszukiwania autodiagnozy we współczesnym świecie. Badaczka przedstawiła zagadania związane z podejmowaniem ,leczenia" na podstawie autodiagnozy obiektywnie nieistniejących chorób, a także samoleczenia schorzeń zdiagnozowanych klinicznie za pomocą metod o niepotwierdzonej skuteczności, uznanych na podstawie badań klinicznych za nieskuteczne lub szkodliwe dla pacjenta. Następnie głos zabrała dr hab. prof. UAM Barbara Walkiewicz wygłaszając referat pt. Mapy gatunków w polskim i francuskim dyskursie medycznym, która przeprowadziła analizę kontrastywną map gatunków obsługujących polski i francuski dyskurs medyczny w zakresie komunikacji szpitalnej. Jako ostatni głos zabrał dr hab. prof. UWr Waldemar Żarski, który referacie pt. Lekarz. Ewolucja pojęcia i jego aktualizacji tekstowych w polszczyźnie, przedstawił pole leksykalnosemantyczne tego pojęcia i jego tekstowych aktualizacji w polszczyźnie. Następnie obrady przebiegały w dwóch sekcjach. W obu uczestnicy konferencji wysłuchali zróżnicowanych referatów, w których dyskurs para(medyczny) był rozpatrywany w rozmaitych aspektach, jak np. a) dyskurs medyczny w staropolszczyźnie (referaty: dra Jana Kamienieckiego (UWr), Problematyka medyczna w pismach staropolskich polemistów religijnych, teksty i gatunki w dyskursie medycznym, mgra Andrzeja Jędrzejczaka (UAM) Metafora tradu w Biblii Hebrajskiej); b) dyskurs medyczny (referaty: dr Magdaleny Zabielskiej (UAM), Medyczny opis przypadku- ewolucja gatunku i obraz pacjenta, dra hab. Piotra Kładocznego (UZ), Teksty (para)medyczne skierowane do pacjentów z problemami kardiologicznymi, mgr Ewy Kaczmarz (UWr), Wybrane elementy dyskursu medycznego w trip raportach, mgra Kamila Wabnica (UWr) Poradnictwo zdrowotne w przestrzeni internetowych forów dyskusyjnych. Analiza genologiczna); c) słownictwo specjalistyczne, medyczne (referaty: dr hab. Magdaleny Graf (UAM), Wizyta u Dr. Vita - suplementy diety i (para)leki okiem onomasty, dra Jarosława Pucały (ATH), Stownictwo tagrowe dotyczace choroby głodowe, dr Renaty Kozieł (UŚ), Funkcje semantyczne czasowników i przymiotników wchodzących w relacje syntagmatyczne z leksemami ból w języku polskim i Schmerz w języku niemieckim, mgr Natalii Dobrzenieckiej (UWr) Rejestr stylistyczny wspótczesnych poradników dietetycznych, mgra Adama Dombrowski (UWr) Terminologia medyczna w poradnikach zdrowia; d) przejawy dyskursu medycznego w mediach (referaty: dr Marceliny Kałasznik (UWr), 
Celebrytoza i celebrytyzm - medialne choroby wspótczesności?, dr Małgorzaty Sokół (USz) Co-constructed narratives in blogs by healthcare professionals. Genre emergence and adoption, dr Joanny Smól (UAM), Poradnictwo medyczne w prasie kobiecej lat 60. i 90. XX wieku, mgr Magdaleny Nowakowskiej (UŁ), Dyskurs na temat zdrowia $w$ mediach mainstreamowych na przyktadzie portalu Onet.pl, mgr Marii Rudnickiej (UWr) ,,Stare i piękne, czyli beautymania jako sposób na zachowanie mtodości w tekstach tygodnika ,Polityka” w okresie 2005-2015); e) dyskurs medyczny w praktyce, zdrowie i choroba jako obraz literacki, zdrowie w kulturze (referaty: dr Moniki Ładoń (UŚ), ,Niewidoczna harmonia”. Między zdrowiem a choroba, mgr Beaty Koper (UAM), Dyskurs medykalizacyjny i demedykalizacyjny w literaturze polskiej po 1989 roku, dr Anny Burzyńskiej-Kamienieckiej (UWr), Mam żótta febrę, trąd, morówkę. Obraz choroby w dawnych podręcznikach do nauczania języka polskiego jako obcego (XVI-XVII w.), dr Karolina Zioło-Prużak (UKSW), Co o naszym zdrowiu mówimy innym? Przedstawienie problematyki zdrowia i choroby w podręcznikach do nauki języka polskiego jako obcego); f) językowo-kulturowy obraz lekarza (referaty: dr Karoliny Sykulskiej, Komunikacja lekarska jako narzędzie realizacji praw pacjenta, dr Karoliny Waliszewskiej (UAM), Komentarze oceniające lekarzy winternecie jako gatunek tekstu w polskim i niemieckim dyskursie paramedycznym, dr Beaty Szpingier (UAM), Co mówi lekarz, by pacjent go zrozumiat - o środkach językowych i sposobach nprzekazywania wiedzy specjalistycznej w kontekście medycyny, mgr Aleksandry Szugajew (UW), Life-writing by medical professionals: the doctor to patient change of perspective in Dr. Paul Kalanithi's memoir When Breath Becomes Air). W sesji planarnej drugiego dnia na zakończenie konferencji referat wygłosiła dr hab. prof. UWr Edyta Zierkiewicz (UWr), który był zatytułowany: Od choroby śmiertelnej, przez przewlekta, do choroby jako afirmacji życia. Zmiany kulturowego obrazu raka piersi w medialnych dyskursach o celebrytkach jako idealnych pacjentkach. Referat był poświęcony edukacyjnej funkcji prasy popularnej na przykładzie konstruowania dyskursu choroby nowotworowej. Dr hab. prof. IS PAN Lucyna Jankowiak zaprezentowała wyniki badań w referacie pt. Trwatość synonimii w polskiej terminologii medycznej przełomu XIX i XX wieku, którego podstawą był materiał zaczerpnięty z dwóch słowników medycznych: „Słownika terminologii lekarskiej polskiej” z 1881 r. i „Słownika lekarskiego polskiego” z 1905 r.. Porównanie szeregów synonimicznych polskich terminów (nazwy chorób) obecnych w obu słownikach pozwoliło odpowiedzieć na pytanie o skalę eliminowania synonimii na przestrzeni 24 lat. Dr hab. Aneta Firlej-Buzon wygłosiła referat pt. Zdrowie i medycyna na Dolnym Ślasku w latach 1945-1948 w świetle rozporzadzeń władz m. Wrocławia i regionu, omawiając sylwetki pionierów wrocławskiej medycyny w zakresie upowszechniania służby zdrowia wspierali dolnośląscy urzędnicy. Publikowane przez nich rozporządzenia, zarządzenia i ogłoszenia obecne w krajobrazie medialnym Dolnego Śląska od maja 1945 roku ujawniły wiele nieznanych faktów z zakresu organizowania publicznej służby zdrowia. Dr hab. prof. UPH Andrzej Borkowski wygłosił referat pt. Lekarz i pacjent $w$ staropolskim dyskursie literackim (w kręgu fraszkopisarstwa XVI $i X V I I$ w.). Celem referatu było rozpoznanie i opis relacji lekarz - pacjent $\mathrm{w}$ dawnej odmianie dyskursu literackiego. Bazą źródłową dla prezentowanych badań była 
drobna twórczość pisarzy staropolskich: Jana Kochanowskiego, Wacława Potockiego $\mathrm{i}$ innych.

Stale rosnąca i rozwijająca się wiedza medyczna i jej coraz powszechniejsza dostępność, wraz z rozwojem technologii i społecznym naciskiem na dbanie o zdrowie i wygląd, powodują, że zdrowie jako wartość ponadczasowa i fenomen ponadkulturowy stanowi interesującą perspektywę badawczą nie tylko dla nauk medycznych, ale także dla językoznawstwa.

Dyskurs medyczny realizują rozmaite teksty, również kultury, które były przedmiotem konferencji naukowej w IFP UWr. Problematyka konferencji obejmowała m. in. typologię tekstów w dyskursie medycznym, językowo-kulturową wizję lekarza i przejawy dyskursu (para)medycznego w mediach.

Wyniki badań prezentowane podczas interdyscyplinarnej konferencji przyczynią się do pogłębienia stanu wiedzy nie tylko w tym zakresie tematycznym, ale również w odniesieniu do badania procesów medykalizacji życia codziennego.

Konferencja zgromadziła wielu słuchaczy, którymi byli zarówno pracownicy naukowi Uniwersytetu Wrocławskiego, jak i sami studenci. Dzięki temu po każdej prelekcji trwała ożywiona dyskusja, przedstawiano ciekawe spostrzeżenia.

Adam Dombrowski Uniwersytet Wrocławski

\section{Teraźniejszość i przysztość hungarologii, Poznań, 30.11-01.12.2017}

Celem konferencji było stworzenie forum dla polskich, węgierskich i innych hungarologów do dyskusji nad aktualnymi problemami hungarologii i wymiany doświadczeń na polu dydaktyki w ramach tej dziedziny nauki. Konferencja była jednocześnie okazją do godnego uczczenia 25. rocznicy powołania jej organizatora - Filologii Węgierskiej na Uniwersytecie im. Adama Mickiewicza w Poznaniu.

W uroczystej inauguracji udział wzięli wygłaszając przemówienie I. Sekretarz Ambasady Węgier w Polsce prof. Gábor Lagzi, Dziekan Wydziału Neofilologii UAM prof. Aldona Sopata, Dyrektor Instytutu Językoznawstwa UAM prof. Piotr Wierzchoń, Dziekan Wydziału Neofilologii UAM w okresie powoływania Filologii Węgierskiej prof. Tadeusz Zgółka oraz jeden z jej założycieli i były kierownik Zakładu Hungarystyki prof. Jerzy Bańczerowski.

Gości powitała kierownik Zakładu Filologii Ugrofińskiej prof. Ilona Koutny, prezentując następnie rys historyczny 25-letniej specjalności. Do wspomnień dołączył ówczesny attaché kulturalny Ambasady Węgier w Polsce prof. István Kovács, specjalizujący się w badaniach nad udziałem Polaków w walkach na Węgrzech pod- 